NBER WORKING PAPER SERIES

DEBT AND FINANCIAL VULNERABILITY ON THE VERGE OF RETIREMENT

\author{
Annamaria Lusardi \\ Olivia S. Mitchell \\ Noemi Oggero \\ Working Paper 23664 \\ http://www.nber.org/papers/w23664
}

NATIONAL BUREAU OF ECONOMIC RESEARCH

1050 Massachusetts Avenue

Cambridge, MA 02138

August 2017

The authors thank Yong Yu for expert programming and research assistance. Additionally, they thank Melinda Morrill, participants at the 2016 Working Longer and Retirement conference at SIEPR/Stanford University, and at the CMV/OECD Seminar on Emerging Trends in Financial Education, Rio de Janeiro, Brazil, for suggestions and comments. We gratefully acknowledge financial support from the TIAA Institute and the Pension Research Council/Boettner Center at the Wharton School of the University of Pennsylvania. Opinions and conclusions expressed herein are solely those of the authors and do not represent the opinions or policy of the funders or any other institutions with which the authors are affiliated. The views expressed herein are those of the authors and do not necessarily reflect the views of the National Bureau of Economic Research.

At least one co-author has disclosed a financial relationship of potential relevance for this research. Further information is available online at http://www.nber.org/papers/w23664.ack

NBER working papers are circulated for discussion and comment purposes. They have not been peer-reviewed or been subject to the review by the NBER Board of Directors that accompanies official NBER publications.

(C) 2017 by Annamaria Lusardi, Olivia S. Mitchell, and Noemi Oggero. All rights reserved. Short sections of text, not to exceed two paragraphs, may be quoted without explicit permission provided that full credit, including $(\odot$ notice, is given to the source. 
Debt and Financial Vulnerability on the Verge of Retirement

Annamaria Lusardi, Olivia S. Mitchell, and Noemi Oggero

NBER Working Paper No. 23664

August 2017

JEL No. D14,D15

\begin{abstract}
$\underline{\text { ABSTRACT }}$
We analyze older individuals' debt and financial vulnerability using data from the Health and Retirement Study (HRS) and the National Financial Capability Study (NFCS). Specifically, in the HRS we examine three different cohorts (individuals age 56-61) in 1992, 2004, and 2010 to evaluate cross-cohort changes in debt over time. We also use two waves of the NFCS (2012 and 2015) to gain additional insights into debt management and older individuals' capacity to shield themselves against shocks. We show that recent cohorts have taken on more debt and face more financial insecurity, mostly due to having purchased more expensive homes with smaller down payments.

Annamaria Lusardi

The George Washington University

School of Business

2201 G Street, NW

Duques Hall, Suite 450E

Washington, DC 20052

and NBER

alusardi@gwu.edu

Olivia S. Mitchell

University of Pennsylvania

The Wharton School

3620 Locust Walk, St 3000 SH-DH

Philadelphia, PA 19104-6302

and NBER

mitchelo@wharton.upenn.edu

Noemi Oggero

University of Turin

Collegio Carlo Alberto

Via Real Collegio 30

10024 Moncalieri (Torino)

Italy

noemi.oggero@carloalberto.org
\end{abstract}




\section{Debt and Financial Vulnerability on the Verge of Retirement}

The United States has witnessed a steady rise in access to financial credit and opportunities to borrow over time, yet many individuals lack the financial know-how to manage the complex new financial products increasingly available in the financial marketplace. ${ }^{1}$ As a consequence, it is key to learn more about how people borrow and manage debt in the modern economy. ${ }^{2}$ In particular, older persons today appear more likely to enter retirement in debt than in past decades. Importantly, the greater indebtedness of people on the verge of retirement has several macroeconomic implications. For example, higher debt levels make households more sensitive to increases in interest rates. Moreover, retirees may need to devote a rising proportion of their incomes to servicing their debt. This paper evaluates the factors associated with older American's debt patterns and debt management practices to trace how these patterns have changed over time and to evaluate whether these practices leave people particularly vulnerable in old age.

To this end, we examine older individuals' debt patterns using the Health and Retirement Study (HRS) and the National Financial Capability Study (NFCS). With the HRS, we compare three different cohorts of people on the verge of retirement (age 56-61) as well as people slightly older (age 62-66). We study the determinants of debt and how debt across the cohorts has evolved. We also discuss the potential consequences of our findings regarding indebtedness on the verge of retirement. ${ }^{3}$ With the 2012 and 2015 NFCS, we explore rich new information on

\footnotetext{
${ }^{1}$ See, for instance, Lusardi and Mitchell (2007, 2008, 2011a, b, c, 2014) and Lusardi, Mitchell, and Curto (2014).

${ }^{2}$ E.g., Lusardi and Tufano (2015), Lusardi and de Bassa Scheresberg (2013), and Lusardi and Mitchell (2016).

${ }^{3}$ Our prior work examined saving and asset building among those age 50+ (Lusardi and Mitchell, 2007, 2011a).
} 
debt and debt management among the same age groups (56-61 and 62-66), highlighting many signs of financial distress among individuals who should be close to the peak of their wealth accumulation profiles. The NFCS data also enable us to examine the determinants of financial fragility and over-indebtedness of individuals on the cusp of retirement.

Our focus on debt is important for several reasons. First, debt typically grows at interest rates higher than those which can be earned on investments. For this reason, debt management is critical for those seeking to manage their retirement assets conservatively. Second, over time, families have gained easier access to home mortgages and home equity lines of credit, compared to the past. ${ }^{4}$ They have also been required to make smaller down payments when they take out mortgages than in years gone by. In tandem, as sub-prime mortgages proliferated, credit became increasingly accessible to consumers with low credit scores, little income, and few assets. Consumer credit via credit card borrowing has also become more accessible, and this type of unsecured borrowing has risen over time. Third, alternative financial services including payday loans, pawn shops, auto title loans, tax refund loans, and rent-to-own shops, have proliferated in

many states (Lusardi and de Bassa Scheresberg, 2013). Fourth, it is important to identify financially fragile families, which can be sensitive to shocks in retirement. Finally, the 20082010 financial and economic crisis was largely driven by borrowing behavior, so understanding debt could help us avoid a repeat of past errors.

\section{Prior Literature}

The massive debt run-up by American households has been noted in a number of previous studies. Total household debt rose quickly before the financial crisis, doubling between

\footnotetext{
${ }^{4}$ Lower interest rates reduced the effective cost of accessing home equity (Hurst and Stafford, 2004).
} 
2000 and 2008, and peaking at \$12.68 trillion in the third quarter of 2008 (Federal Reserve Bank of New York, 2016). Yet by the end of 2016, aggregate household debt was still $\$ 12.58$ trillion, just 0.8 percent below the all-time peak. And as of the fourth quarter of 2016, mortgage originations (which include refinanced mortgages) were at their highest level seen since the beginning of the Great Recession (Federal Reserve Bank of New York, 2017). Moreover, Vornovytskyy, Gottschalck, and Smith (2011) showed that individuals age 55-64 and 65+ experienced the largest relative increases in household debt (using Census Bureau data). Specifically, people age 55-64 saw a 64 percent increase in median household debt between 2000 and 2011, and median household debt more than doubled among those age 65+.

Given these findings, several policy analysts have expressed concern that debt has risen to worrisome levels in America. ${ }^{5}$ The media has also taken notice with articles exhorting people to pay down their debt as they near retirement (e.g., Derousseau, 2016). Several authors have documented the types of debt held at later stages in the life cycle, including Bucks et al. (2009) who showed that more than half $(55 \%)$ of the American population age 55-64 carried home mortgages, and about the same fraction (50\%) had credit card debt. Among those age 65-74, two-thirds held some form of debt; almost half had mortgages or other loans on their primary residences; over one-third held credit card debt; and one-quarter had installment loans.

Others have noted that managing debt and other financial matters is problematic for many older adults. For instance, Agarwal et al. (2009) reported an inverse U-shaped age pattern of financial decision-making quality in 10 financial areas mostly related to debt. For instance, they noted that fees and interest paid tend to be lowest for those in their early 50's and rise thereafter; moreover, older individuals pay some of the highest costs for financial services. Furthermore, it

\footnotetext{
${ }^{5}$ For a few recent examples, see AARP (2013), Cho (2012), Copeland (2013), Pham (2011), and Securian (2013).
} 
has been suggested that debt drives decisions about retirement and the age at which workers start claiming Social Security benefits (Butrica and Karamcheva, 2013).

Of late, there has also been an increase in the proportion of older Americans filing for bankruptcy. Pottow (2012) argued that the age 65+ demographic has been the fastest-growing in terms of bankruptcy filings, which stood at $2 \%$ in 1991 but rose by more than three times by 2007. Credit card interest and fees were the most-cited reason for bankruptcy filings, with twothirds of those filing providing these reasons. People age 55+ held widespread credit card debt and paid more in late payments and for exceeding their credit limits, despite the fact that they should have been at the peak of their wealth accumulation profiles (Lusardi, 2011; Lusardi and Tufano, 2009, 2015). Several studies have also found a link between debt management and financial literacy. Specifically, the least financially literate reported incurring high fees and using high-cost borrowing regularly, and they also indicate that their debt loads were excessive and they often could not judge their debt positions (Lusardi and Tufano, 2015). This group was also more likely to borrow from their 401(k) and pension accounts (Lu et al., 2017; Utkus and Young, 2011), and they used high-cost methods of borrowing such as payday loans (Lusardi and de Bassa Scheresberg, 2013).

Some recent studies have sought to understand the reasons for this rapid increase in debt among American adults. One commonly-cited culprit is the rapid rise in housing prices during the 2000's, paired with the growth of easier mortgages (Christelis, Ehrmann, and Georgarakos, 2015; Dynan and Kohn, 2007; Mian and Sufi, 2011). Another often-cited explanation is that technological change in the lending market induced risk-based pricing, reduced distribution costs, and contributed to other innovations that made it easier for households to borrow (Dynan, 2009; Edelberg, 2006). Meanwhile, a separate strand of research has argued that improvements 
in the technology of persuasion through nonlinear contracts and uninformative sales tactics have "shrouded" customers' understanding of financial contracts and, in turn, boosted total amounts borrowed and/or the costs of borrowing (Gabaix and Laibson, 2006; Agarwal and Evanoff, 2013; Bertrand et al., 2010; Gine, Martinez Cuellar, and Mazer, 2014; Gurun, Matvos, and Seru, 2016). Yet another strand of literature has cited the impact of income inequality as an explanation for the rapid rise in debt (Kumhof, Ranciere, and Winant, 2015).

That literature does offer useful insights regarding the overall rise in debt, but far less work has been done evaluating older Americans' debt patterns. Moreover, the few extant studies do not look at the determinants of indebtedness close to retirement. For this reason, in what follows, we contribute to the literature with new empirical analyses of debt and debt management among older Americans.

\section{Evidence from the HRS}

The HRS is a panel dataset nationally representative of the US population with both longitudinal/panel and cross-cohort features. Using the rich information derived from the HRS, we have assembled asset and debt information for three cohorts of people on the verge of retirement: those age 56-61 in the HRS baseline group, those age 56-61 in the War Babies group, and those age 56-61 in the Early Boomers group. Subsequently, we examine the slightly older group (those age $62-66) .{ }^{6}$ For each respondent we have comparable data on assets and

\footnotetext{
6 The HRS baseline cohort was born 1931-1941; the War Babies group was born 1942-1947; and the Early Boomer group was born 1948-1953. The 56-61 age group was surveyed in 1992 for the baseline HRS cohort, in 2004 for the War Babies, and in 2010 for the Early Boomers. The 62-66 age group was surveyed in 1998 for the baseline HRS cohort, in 2008 for the War Babies, and in 2014 for the Early Boomers. We also note that the survey included different numbers of respondents per cohort, since the 1992 HRS survey was substantially larger than the subsequent groups. Results reported below use weighted data and all dollar values are expressed in 2015 dollars.
} 
debt. The difference in time periods and age groups allows us to examine how the financial crisis affected the amount of debt that individuals held as they neared and entered retirement.

\section{Cross-Sectional Results}

Table 1 describes the evolution of total debt across the three cohorts of respondents age 56-61. ${ }^{7}$ Total debt is measured in the HRS as the value of mortgages and other loans on the household's primary residence, other mortgages, and other debt (including credit card debt, medical debt, etc.). The percentage of people age 56-61 arriving at the verge of retirement with debt rose from $64 \%$ in the HRS baseline group to $71 \%$ among Early Boomers. Additionally, the value of debt held rose sharply over time. While the median amount of debt in the baseline group was about $\$ 6,800$, it more than quadrupled among War Babies and almost quintupled among Early Boomers (respectively $\$ 31,200$ and $\$ 32,700$, all in 2015 dollars). We also see that the debt distribution appears to have changed across cohorts. The top quartile of the debt distribution held around $\$ 51,000$ in debt in the baseline group $\left(75^{\text {th }}\right.$ percentile), while in the two cohorts surveyed more recently, this same quartile of the population held more than double $(\$ 106,000)$ and almost triple $(\$ 146,800)$ that amount. Additionally, the top 10 percent of the debt distribution $\left(90^{\text {th }}\right.$ percentile) reported debt of over $\$ 272,000$, more than double what had been seen for respondents in this same age range 18 years earlier. Depending on the interest rate charged on this debt, these families would be very likely to face sizeable monthly debt repayments and to carry debt well into retirement. As debt levels increase, borrowers' ability to repay becomes progressively more sensitive to drops in income as well as increases in interest rates. For a given shock, the higher the debt, the higher the probability of defaulting (Cecchetti, Mohanty, and Zampolli, 2011).

\footnotetext{
7 The analysis attributes household assets and debt to each age-eligible individual in the HRS sample. This, in effect, implies that all household assets and liabilities influence married and single respondents when they make economic decisions. An alternative approach might seek to allocate assets and liabilities between members of a couple, but this is difficult if not impossible, and it would not affect the debt ratios examined below.
} 
Moreover, Mayer (forthcoming) shows that most households entering retirement age with a mortgage do not fully pay the debt in retirement. In fact, only about 25 to 35 percent of older homeowners with a mortgage in 1992 had paid off their mortgage by the year prior to death.

\section{Table 1 here}

One factor driving this rise in debt across time is the greater value of people's primary residence mortgages for the cohorts surveyed more recently. In the second panel of Table 1, we see that the percentage of people age 56-61 having mortgage debt has risen by eight percentage points, from $41 \%$ in the baseline group to $49 \%$ among Early Boomers. Moreover, mortgage debt amounts grew as well. For instance, looking at the third quartile $\left(75^{\text {th }}\right.$ percentile) of the mortgage debt distribution in the whole sample (not conditional on having a mortgage), we see that mortgage debt more than tripled among Early Boomers compared to the baseline group. The third panel shows that over the same period, the percentage of respondents with loans on their primary residence grew from $11 \%$ to $17 \%$, an increase of $50 \%$. Here too, people's mortgage values rose. The mean value of other mortgages (e.g., on secondary residences) also increased, as can be seen from the fourth panel, though relatively few (4-6\%) held this form of debt. The data show that the growth of housing debt in the boom prior to the Great Recession remains on the balance sheets of many older households today.

The fifth panel of Table 1 indicates that other debt for persons on the verge of retirement also rose across cohorts, from $37 \%$ for the HRS baseline group, to $42 \%$ for the Early Boomers. The debt distributions also became more skewed over time. For instance, those in the $90^{\text {th }}$ decile of the distribution of other debt held about $\$ 8,000$ in debt in the reference group, while those in the same decile held over $\$ 17,000$ and almost $\$ 22,000$ in the War Baby and Early Boomer cohorts, respectively. Because this category includes non-collateralized debt, which comes with 
high interest rates, our findings imply that older Americans are increasingly likely to face high monthly payments to service their debt. ${ }^{8}$ In the course of the recent global financial crisis, central banks have lowered nominal interest rates to record levels (Schmidt 2013). Our concern regarding these indebtedness trends is that older households' debt and financial situation will deteriorate as short-term interest rates start to increase.

Additional insight into older adults' financial situations is provided by the ratios of debt to assets shown in Table 2. Here the total assets measure includes all checking and savings accounts, CDs, money market funds, T-bills, bonds/bond funds, stocks/stock market funds, IRAs, 401(k)s and Keoghs, the value of primary residence and other real estate, vehicles, business equity, and other savings. ${ }^{9}$ We also consider the ratio of housing debt (including home mortgages and other home loans) to the value of the house and the ratio of other debt to the value of liquid assets, in which the latter are defined as the sum of checking and savings accounts, CDs, money market funds, T-bills, bonds/ bond funds, and stocks/stock market funds. These ratios allow us to evaluate older adults' leverage ratios and to assess how much of their home loans they have paid off already. This, in turn, allows us to examine whether or not people will enter retirement having to make monthly mortgage payments.

\section{Table 2 here}

Comparing Table 2 with Table 1, we see that it is not just the value of debt that has increased over time, but the proportion of debt to assets as well. Thus, Americans age 56-61 today are much more leveraged than were their counterparts in the past. For example, the first panel of Table 2 shows that the median value of total debt over total assets was rather small for

\footnotetext{
${ }^{8}$ For example, it takes a monthly payment of $\$ 547$ to pay off a debt of $\$ 21,000$ with an associated annual percentage rate (APR) of $20 \%$ in five years. Similar findings are reported by Butrica and Karamcheca (2013).

${ }^{9}$ We use the measure of wealth provided in the RAND HRS, with wealth values winsorized at the top and bottom $1 \%$.
} 
the HRS baseline cohort, i.e., only about $4 \%$, but this ratio rose to $11 \%$ and $15 \%$ in the War Baby and Early Boomer cohorts. ${ }^{10}$ Moreover, a sizable fraction of Early Boomers had ratios over 50\% and some held debt worth as much as $90 \%$ of total assets. Debt is not necessarily a problem if homeowners have more assets to pay back the debt. However, as Mayer (forthcoming) also shows when considering the evolution of mortgage debt versus financial assets, not only has debt increased as a share of home values among the elderly, but it also increased relative to financial assets.

One of the reasons for the observed increase in leverage is that people nearing retirement accumulated more debt on their homes over time. The second panel of Table 2 shows that many Early Boomers nearing retirement (age 56-61) were far more leveraged than War Baby and HRS baseline cohorts: at the median, the ratio of primary mortgage to home value rose from $5 \%$ to $30 \%$, and the top ten percent of the group went from $63 \%$ to $92 \%$. This means that Early Boomers on the verge of retirement will need to continue servicing their mortgages well into retirement.

Of course mortgage debt rose in part because more recently surveyed cohorts purchased more expensive homes than their predecessors. For instance, the median HRS baseline respondent in his or her late fifties had a home worth about $\$ 144,000$, and by 2004 , the median War Baby household of the same age owned a home worth $\$ 187,000$ in constant dollars (fourth panel of Table 2). Home values for the median Early Boomer were even higher, at $\$ 218,000$ in 2010, even with the collapse of the housing market in the Great Recession, which sliced home values by half in some states. The trend toward buying more expensive homes also meant that the percentage of total assets accounted for by the home was larger for cohorts surveyed more

\footnotetext{
${ }^{10}$ Ratios are defined only for those who have a strictly positive value of total assets.
} 
recently. Thus at the median of the debt ratio distribution, the baseline cohort held about $46 \%$ of their total assets in their primary residence, but for the Early Boomers the percentage was 50\% (third panel of Table 2). In our previous work, we documented the great importance of housing in Baby Boomers' wealth holdings (Lusardi and Mitchell, 2007).

The fifth panel of Table 2 indicates that non-mortgage debt also rose as a percentage of liquid asset values, and for some people, it rose a great deal (we note that Table 2 reports these ratios conditional on the respondent having strictly positive liquid assets). A much higher proportion of Early Boomer households held such debt worth the same as, or more, than their liquid assets, and at the mean the ratios rose by ten times. Again, this implies that older people must increasingly borrow or sell off other (less) liquid assets to pay off this non-collateralized debt. It is also interesting that a large fraction of respondents had liquid assets even while carrying debt. Since debt is likely to incur higher interest rates than bank accounts pay out, some families may be overlooking opportunities to better manage their balance sheets.

An additional diagnostic of changes in indebtedness over time is available from an analysis of the ratio of total debt to total income. This proportion provides another indicator of the ability to repay debt. In line with the above, the sixth panel of Table 2 indicates that the debt to income ratio also rose across cohorts, with the median ratio growing from $14 \%$ to $45 \%$ and $50 \%$ across the three cohorts. This trend is confirmed by other studies (e.g., Dynan and Kohn, 2007), even though some decline in the median debt to income ratio was observed in the aftermath of the financial crisis. Bricker et al. (2014) found that in 2013, the median debt-toincome ratio for debtors went down from the level seen in 2010, to close to that witnessed in 2004. In our data, we can see that the ratio slightly increased for the cohort surveyed in 2010 compared to the War Baby cohort (surveyed in 2004), notwithstanding the deleveraging after the 
Great Recession. This increase in debt to income ratios makes households more vulnerable to shocks and to increases in interest rates. Movements in market rates alter the terms of new borrowing as well as the burden imposed by previous borrowing. When debts are large relative to incomes, this effect is accentuated so that a given change in interest rates has a larger effect on debt service and thus on the funds available for consumption (Dynan and Kohn, 2007). The increased indebtedness makes the household sector more exposed to interest rate risk, particularly where variable rate mortgages are prevalent, and American households have increased their take-up of variable rate mortgages or hybrid mortgages (Debelle, 2004). Furthermore, the easing of liquidity constraints and the increased indebtedness imply that household consumption, and hence the economy, are likely to be more sensitive to changes in household expectations about the future path of interest rates.

Next we turn to several financial vulnerability indicators that offer an assessment of how individuals fare as they near retirement. ${ }^{11}$ Adults close to retirement would be anticipated to be at or near the peak of their wealth accumulation process, and one important decision after retirement is how to decumulate wealth. As noted above, however, recent cohorts will also need to manage and pay off their rising debt burdens in retirement. This is made more difficult by the fact that older persons often move some of their assets to fixed income assets. In addition, if equity returns are lower in the future than they were in the past (as many predict), it will be important for current older cohorts to manage assets and liabilities wisely and pay off some of their higher-interest debt first. Accordingly, it appears that cohorts entering retirement will need to ensure that their income and asset drawdowns suffice not only to cover their target consumption streams, but also to service their mortgage and other debt during retirement. This is

11 The present analysis excludes pension and Social Security wealth. While these are important components of total wealth, many of the individuals in the cohorts we are examining still have defined benefit plans which often prohibit taking a lump sum. 
made increasingly complex by older workers' lack of flexibility in adjusting mortgage payments apart from selling their homes, moving to smaller homes, or engaging in reverse mortgages, which many older cohorts in the past seemed unwilling to do, at least until late in the life cycle (Venti and Wise, 1990, 1991; Hurd, 1990).

Table 3 underscores the conclusion that the prevalence of financial vulnerability has risen over time. Fewer than $10 \%$ of the HRS baseline respondents approached retirement with debt to asset ratios above 0.5 , but over one-fifth (22\%) of Early Boomers did so, as shown in the first panel. ${ }^{12}$ Moreover, this pattern was already observed prior to the financial crisis, since the ratio of debt to assets was already higher among War Babies (15\%) compared to the baseline group. As noted earlier, part of this increase in debt can be attributed to the rise in home mortgages, which led to younger cohorts nearing retirement with far higher ratios of mortgage debt to home values. In particular, this explains why the collapse of the housing market starting in 2007 exacerbated the role of mortgages and other loans in driving near-retirement debt.

\section{Table 3 here}

The second panel of Table 3 shows that only about $16 \%$ of the HRS baseline group (age 56-61) had loan/value ratios on their primary residences greater than 0.5 , compared to $26 \%$ of the War Babies and almost 35\% of the Early Boomers. The third panel confirms that nonmortgage debt to asset ratios also rose rapidly over time. Accordingly, Early Boomers will likely need to dedicate some of their liquid wealth to pay off debt in retirement, and hence this cohort is more exposed to the negative consequences of interest rate increases than their counterparts who were surveyed earlier.

\footnotetext{
12 These values refer only to those with strictly positive assets.
} 
The last panel in Table 3 focuses on measured changes in the prevalence of very low wealth, defined here as having less than $\$ 25,000$ in savings. We focus on this cutoff as it is about half of median household income, and it is not very high relative to a health shock or some other costly surprise. Our results show that $15-16 \%$ had such low net worth in the HRS baseline and in the War Baby cohort, while $24 \%$ of the Early Boomer cohort had low wealth. Accordingly, it seems clear that over time, savings have shrunk and debt has ballooned for Americans on the verge of retirement.

\section{Debt Patterns in Perspective}

Our analysis so far shows that in recent years, cohorts of people age 56-61 have taken on substantially more debt and are more financially vulnerable than their predecessor cohorts, mostly because they purchased more expensive homes with smaller down payments. A closer look at debt burdens of older persons is provided by a tandem analysis of respondents 62-66 years old for the HRS baseline, the War Babies, and the Early Boomers. ${ }^{13}$ This additional analysis helps us interpret the increase in debt observed in the 56-61 age group and understand to what extent changes in debt patterns affect retirement security.

The evolution across cohorts of debt and debt ratios for people age 62-66 is described in the right panels of Tables 1 to 3. In line with the younger group, the indebtedness of older individuals also rose over time. For example, Table 1 shows that the percentage of people age 62-66 with debt rose from 52\% in the HRS baseline to 64\% among Early Boomers; and the median debt increased from $\$ 580$ in the HRS baseline to $\$ 8,800$ (fifteen times) among War Babies and \$12,000 (twenty-one times) among Early Boomers.

\footnotetext{
${ }^{13}$ As explained before, the HRS baseline cohort was born 1931-1941; the War Babies group 1942-1947; and the Early Boomer group 1948-1953. In this section we focus on those age 62-66, surveyed in 1998 for the baseline HRS cohort, in 2008 for the War Babies, and in 2014 for the Early Boomers.
} 
In addition to confirming the dramatic increase in debt across cohorts, Table 1 also shows that older people generally hold less debt than younger people. For instance, in the HRS baseline cohort, $64 \%$ of those age 56-61 were debt holders, and the percentage was lower (52\%) among those age 62-66. This difference persists in the later cohorts, with $71 \%$ of Early Boomers age 56-61 having debt versus 64\% of Early Boomers age 62-66. Moreover, older debt holders also had less debt: Among Early Boomers, the median total debt of the older group was only about one-third of the median debt of people age 56-61 (\$12,000 compared to $\$ 32,700)$. The diminished financial stability in retirement due to greater amounts of debt is likely to continue as younger cohorts are nearing retirement age with more debt than previous cohorts. The fact that indebtedness decreases as people age most likely means that debt continues to be repaid in old age. It may also indicate that older people today were more conservative about taking on debt near retirement than today's younger generation is.

The ratios of debt to assets reported in Table 2 also show that the proportion of debt increased across cohorts for those age $62-66$. For instance, the median ratio of primary mortgage to home value rose from $0 \%$ in the HRS baseline to $13 \%$ among Early Boomers. However, leverage ratios declined with age. Median debt to income ratios, which indicate potential problems repaying debt, were twice as large among persons age 56-61 compared to those age 62-66 in the Early Boomer cohort. We interpret the evidence that people in their 50's will need to manage a great deal of debt at older ages as having unfortunate implications for retirement security. The higher debt to income ratio means that people on the verge of retirement will be more exposed to shocks and will remain exposed for a longer period of time than in the past (Debelle, 2004). Consistent with the results discussed above, individuals in the older group (62- 
66) are less financially vulnerable, even though their vulnerability indicators such as high debt to asset ratios and low wealth rose over time (Table 3).

Multivariate Regression Analysis

To further examine the factors associated with financial vulnerability among older Americans, Table 4 summarizes results from a multivariate regression analysis on the four outcomes just discussed, for the 56-61 and 62-66 age groups. That is, the multivariate analysis shows which factors are associated with having (a) a total debt/asset ratio $>0.5$, (b) a ratio of primary residence loans to home value $>0.5$; (c) other debt/liquid asset ratio $>0.5$; and (d) total net worth $<\$ 25,000$.

Table 4 here

Confirming our earlier tabular results, all of the cohort indicators are statistically significant and positive for all four dependent variables. This implies that both the War Babies and Early Boomers at age 56-61 and 62-66 were more likely to be in debt and be financially vulnerable relative to the HRS baseline reference group. In other words, our directional conclusions from Tables 1-3 are supported even after including controls for potential crosscohort differences in socio-demographic factors (these models also control for age, marital status, gender, number of children ever born, race, educational attainment, income, and whether they reported being in poor health). Moreover, results show that for all three debt-to-asset measures, the Early Boomers held significantly more debt and were significantly more financially vulnerable compared to the War Babies.

We mention in passing that some of the socio-demographic controls included in Table 4 are significantly associated with respondent financial vulnerability. For instance, being unmarried, nonwhite, less educated, and having lower income rendered respondents much more 
likely to be financially vulnerable. Additional factors significantly associated with greater vulnerability include having had more children and being in poor health. Interestingly, being in poor health is a stronger predictor of financial vulnerability for people age 62-66 compared to those age 56-61.

For the 56-61 age group, we also performed a multivariate regression analysis on the same four outcomes for those married/living with a partner at the time of the survey, and for the non-married subset only. ${ }^{14}$ As in Table 4, both single and partnered Early Boomers age 56-61 were significantly more vulnerable than their counterparts in the baseline HRS cohort. Additionally, we found interesting associations with specific correlates. For instance, poor health was a strong predictor of high debt ratios for the full sample (in particular, non-mortgage debt ratios) and low wealth holdings close to retirement, perhaps because of medical debt. When we split the sample by marital status, we find that this association is quantitatively more important for singles than for couples. Similarly, singles did better when they had higher income compared to those with partners. The role of education is also worth highlighting: compared to high school dropouts, singles with a college degree were markedly wealthier and less likely to have much debt.

\section{Evidence from the NFCS}

We turn next to an analysis of the 2012 and 2015 NFCS surveys. These data nicely complement the HRS analysis in two ways. First they provide more recent information, and second, they include a unique and rich set of questions about debt and debt management. ${ }^{15}$ The 2012 wave can readily be aligned with the 2010 wave of HRS respondents to show that the two

\footnotetext{
14 The results are available upon request.

${ }^{15}$ For information on the NFCS, see Lusardi (2011).
} 
data sources yield similar conclusions. ${ }^{16}$ The 2015 NFCS provides very current information and includes additional questions about debt and indicators of retirement preparedness. ${ }^{17}$

We examine respondents in the same age groups as those studied in the HRS data from both the 2012 and 2015 waves of the NFCS. We do so to focus on the most recent cohort of individuals on the verge of retirement, as above, but several years after the collapse of the housing market and the financial crisis.

The first two columns of Table 5 provide several indicators of both debt distress and financial vulnerability, focusing first on people age 56-61. Once again, we see that mortgages and other debt were problematic for many near-retirees. In 2012, about $17 \%$ of homeowners (8\% of respondents) reported being underwater, owing more on their homes than they thought they could sell them for. Outcomes improved by 2015 , but $9 \%$ of homeowners were still underwater. Moreover, $16 \%$ of near-retirees had been late with mortgage payments at least once in 2012 (the percentage improved in 2015), and about $3 \%$ had faced a home foreclosure in $2012 .{ }^{18}$

\section{Table 5 here}

As far as non-mortgage debt is concerned, many near-retirees in both waves reported that they did not pay off credit card balances in full (if they had them); more than half of credit card holders carried credit card debt in 2012, a percentage that slightly decreased to $46 \%$ in 2015 .

\footnotetext{
${ }^{16}$ Nevertheless, this survey does not report information about debt levels.

${ }^{17}$ Even though the age group does not align, as age was not a continuous variable in the 2009 NFCS, the data from the 2009 NFCS wave align well with data from the HRS. For example, comparing respondents who were 57-62 years old in 2009 with the 2008 HRS cohort (the cohort closer to the NFCS data in terms of time) confirms that statistics are rather similar between surveys. For example, similar to the 2008 HRS cohort, more than half of NFCS respondents who own their home get close to retirement carrying a mortgage. The NFCS data also show that down payments have been decreasing over time; those who recently bought homes had put down only 5 or 10 percent. Moreover, the 2009 NFCS shows that many older respondents pay the minimum only on their credit cards and that a sizeable proportion have made use of high-cost methods of borrowing, such as payday loans, pawn shops, etc. For more information, see Lusardi and Mitchell (2013).

18 This information is not available in the 2015 NFCS.
} 
About one-third of credit card holders engaged in costly borrowing behaviors such as paying only the minimum due or using the card for cash advances. They were also charged fees for late payment or exceeding the limits. Twenty-three percent of people age 56-61 had unpaid medical bills in 2012, a percentage that fell by 2015 , yet $20 \%$ still had unpaid medical bills. We report these statistics, as delaying payments is a form of credit. Additionally, some borrowers used very high-cost methods such as rent-to-own stores, pawn shops, payday loans, and auto title loans. Nearly one-fifth of the 56-61 age group reported having engaged in these methods of borrowing. Turning to other indicators, $6-7 \%$ of those who had retirement accounts borrowed on them, and 5-6\% took a hardship withdrawal. These findings indicate that many older Americans are exposed to illiquidity and face problems in debt management as they approach retirement.

In the last two rows of Table 5, we examine two indicators of financial vulnerability that illustrate near-retirees' perception of their financial situation. While the NFCS does not report respondent assets and debt values, the survey did ask respondents to evaluate their debt and also their capacity to deal with shocks. Specifically, the following question was asked to evaluate people's perceptions of their debt position:

How strongly do you agree or disagree with the following statement: "I have too much debt right now." Please give your answer from a scale from 1 to 7 , where $1=$ strongly disagree, $7=$ strongly agree and $4=$ neither agree nor disagree. Possible answers: 1-7; don't know; prefer not to say.

A second measure of households' financial position probes how people judge their ability to deal with a financial shock. This is our measure of household's financial fragility. ${ }^{19}$ The wording of the question is as follows:

How confident are you that you could come up with $\$ 2,000$ if an unexpected need arose within the next month?

19 This approach was piloted by Lusardi, Schneider, and Tufano (2011). 
Possible answers: I am certain I could come up with the full $\$ 2,000$, I could probably come up with $\$ 2,000$, I could probably not come up with $\$ 2,000$, I am certain I could not come up with $\$ 2,000$, don’t know, prefer not to say.

The $\$ 2,000$ amount was selected to represent a medium-sized shock such as a car or house repair or an out-of-pocket medical bill. This question is particularly informative because in other research we have found that it is related to having precautionary savings and to households' borrowing capacity and debt situation.

There is evidence in the literature that households may borrow imprudently and accumulate too much debt (Hyytinen and Putkuri, forthcoming). Indeed, when asked to evaluate their debt, about $40 \%$ of people age 56-61 indicated they had too much debt in $2012,{ }^{20}$ and the percentage decreased just slightly in 2015 , to $36 \%$. As shown in Figure 1, the proportion of individuals saying they had too much debt is hump-shaped with age, yet it remains quite high among the group nearing retirement. Accordingly, continuing to manage and pay down debt will surely be required for many people during retirement.

\section{Figure 1 here}

Furthermore, 33-35\% of respondents age 56-61 stated they (probably or certainly) could not come up with $\$ 2,000$ in a month's time. Despite the fact that one might expect this age group to be at the peak of its wealth accumulation, many respondents felt they had little or no ability to shield themselves against financial shocks. The age profile in Figure 1 shows that fragility declines initially with age, but it increases in mid-life-perhaps because of child-related expenses - and it declines again later in life. As for debt, however, financial fragility is still high close to retirement.

\footnotetext{
${ }^{20}$ They answered 5, 6, or 7 to the question: "How strongly do you agree or disagree with the following statement: "I have too much debt right now."
} 
Table 6 reports additional information useful in gauging retirement readiness as well as debt and financial vulnerability. Just $41-44 \%$ of respondents age 56-61 were saving, and it is worrisome that fewer than half had ever tried to figure out how much to save for retirement. This is indicative of problems to come, as in our previous work we showed that planners are much more likely to have retirement wealth; moreover, those who plan arrive at retirement with much higher wealth than do non-planners (Lusardi and Mitchell 2007, 2009, 2011b,c, 2014). It is thus not surprising that so many of these respondents age 56-61 (57\%) were worried about running out of money in retirement, as indicated by responses to a new question added to the NFCS in 2015. Accordingly, the Employee Benefit Research Institute data point out that borrowers who have debt or lack a retirement plan are much less confident in their ability to have enough money to fund retirement (Helman, Copeland, and Derhei, 2015).

\section{Table 6 here}

The evidence so far clearly shows that many Americans continue to be burdened by debt and to be financially vulnerable at older ages. To dig more deeply into debt and debt concerns of persons closer to retirement, we compare again our sample of people age 56-61 to persons 62-66 years old. Consistent with the HRS analysis, we again find that the older age group was doing better. The last two columns of Table 5 show that the older group was less likely to report expensive behaviors such as carrying credit card debt, incurring credit card fees, and using highcost borrowing methods. Compared to younger respondents, the older age group reported lower levels of financial vulnerability, yet still over one-quarter (26\%) stated they had too much debt in 2015, and more than one in five $(23 \%)$ were financially fragile. While people's financial situation does seem to improve with age, the older group is still financially distressed. Close to 
half $(47 \%)$ of those age 62-66 worried about running out of money in retirement and just over half $(55 \%)$ had planned for it.

\section{Multivariate Regression Analysis}

Tables 7 and 8 explore the NFCS dataset in more detail using a multivariate analysis of debt and financial fragility indicators. As noted above, respondents were asked if they thought they had too much debt (the indicator goes from 1 to 7 for the question), and we use this variable as a proxy of problems with debt (in place of the ratios we developed for the HRS). We also use an indicator equal to 1 for those who said they could not (probably or certainly) come up with $\$ 2,000$ in an emergency within a month. We explore variation in these indicators using the same socio-demographic controls used with the HRS regressions (age, marital status, number of financially dependent children, gender, race and ethnicity, education, and income). In addition, we are able to include an indicator for whether respondents said they experienced a large and unexpected drop in income in the previous year. The NFCS, unlike the HRS, also included a very valuable set of questions on financial literacy, permitting us to assess respondents' basic financial literacy. ${ }^{21}$ We can therefore include a financial literacy index (constructed as the number of correct answers to the five financial literacy questions). As these variables are measured similarly in both waves, we pool the surveys together and use a year dummy to test for differences across time.

\section{Tables 7 and 8 here}

Regressions on self-assessed debt appear in Table 7 for the 56-61 and 62-66 age groups, where we see that results are consistent across the two age groups. The evidence shows that older and higher income persons were less likely to report being in debt, while having had more

21 The NFCS includes five questions assessing respondent numeracy, knowledge of inflation, risk diversification, mortgages, and basic asset pricing concepts (Lusardi, 2011). 
children and being African-American were associated with reporting excessive debt. Those who had experienced a large and unexpected income drop in the previous year also agreed they were over-indebted, suggesting that shocks play a role in debt accumulation close to retirement. Finally, financial literacy is negatively related to reports of excessive debt. We conclude that shocks do predict debt accumulation among older Americans, but having resources is not enough. People also need the capacity to manage those resources if they are to stay out of debt as they head into retirement. ${ }^{22}$

In Table 8 we explore the factors associated with respondents' stated ability to come up with $\$ 2,000$ within a month (the HRS reports whether respondents have less than $\$ 25,000$ in savings, which is roughly the monthly value of $\$ 2,000$ multiplied by 12 ). As with the HRS, the NFCS results show that men and those with higher income are more likely to have such liquidity. Also consistent with HRS results, gender plays a role just for the younger group. Minorities like African-Americans and Hispanics were more likely to say they could not come up with $\$ 2,000$ within 30 days. Table 8 also shows that the number of dependent children is positively associated with financial fragility for people age 56-61 but not for the older group, suggesting some potential for a "catch-up" after children leave home. Additionally, having experienced an income shock made respondents more likely to report being financially fragile. Overall, people who reported experiencing income shocks were $14-15$ percentage points more likely to be fragile. Education also plays an important role here: those with high school or more education were substantially less likely to be financially vulnerable. Yet education is only a part of the story: Table 8 shows that financial literacy is also a key factor. Being able to answer one additional financial literacy question correctly was associated with a lower probability (by 3-4 percentage

22 One could argue that financial literacy is a choice variable and one cannot simply perform OLS regressions. While our analysis here aims to be only descriptive, in other papers we have shown that the OLS estimates understate the true effect of financial literacy. 
points) of being financially fragile. In other words, financial literacy has an independent effect on reducing financial frailty, above and beyond the impact of education.

\section{Conclusions and Policy Relevance}

Prior to the recent financial crisis and Great Recession, consumer credit and mortgage borrowing expanded rapidly, leaving relatively unsophisticated consumers in the historically unusual position of being able to decide how much they could afford to borrow. It is important to learn whether and how indebtedness and financial vulnerability of cohorts on the verge of retirement changed in the wake of the economic crisis, and understand likely future consequences. Debt among older persons may increasingly be a factor in elder bankruptcy, and even in determining lifetime wealth sufficiency and retirement security.

Our paper has analyzed older persons' debt and debt management practices using data from both the HRS and the NFCS. Specifically, we examined three different cohorts of older individuals in the HRS. This analysis provided insights into cross-cohort changes in debt indicators over time. We also explored two recent waves of the NFCS, 2012 and 2015, which showed how older persons manage their debt on the verge of retirement and their capacity to shield themselves against shocks.

Our goal was to assess how and why wealth and debt indicators among older persons has evolved over time, and the potential consequences of this evolution for retirement security and the whole economy. We find that the cohorts surveyed more recently have taken on substantially more debt and face more financial insecurity as they near retirement, mostly due to having purchased more expensive homes with smaller down payments. Regardless of whether older 
persons are over-indebted, the larger stock of household debt has important macroeconomic implications. In fact, people on the verge of retirement will be more sensitive to fluctuations in interest rates - particularly if they are unexpected — and the current low interest rate environment is likely to change. Comparing the 56-61 and 62-66 age groups, we show that indebtedness decreased as people aged. Factors reducing exposure to debt include having higher income, more education, and greater financial literacy. Factors associated with greater financial vulnerability include having had more children, being in poor health, and experiencing unexpected large income declines. Thus, shocks do play a role in the accumulation of debt close to retirement, but having resources is insufficiently protective. That is, people also need the capacity to manage those resources if they are to stay out of debt as they head into retirement. This finding complements our recent analysis which found that financial literacy can explain $30-40 \%$ of wealth inequality (Lusardi, Michaud, and Mitchell, 2017).

It is interesting that most theoretical models of household portfolios to date have tended to focus on household portfolio patterns without devoting much attention to debt patterns (e.g., Lusardi, Michaud, and Mitchell, 2017; Delavande, Rohwedder, and Willis, 2008; Chai et al., 2011). Our research suggests that analysts and policymakers should explore ways to enhance debt management practices as they examine factors driving retirement security. The fact that interest rates charged on debt are usually much higher than rates that people can earn on their savings is generally not taken into account. Moreover, existing models have tended to overlook the fact that interest rates charged to individuals are not fixed but can be shaped by people's behavior. Our paper thus motivates additional research on key aspects of debt and debt management to inform future policy. 


\section{References}

AARP. (2013). "In the Red: Older Americans and Credit Card Debt.” AARP Public Policy Institute Report. www.aarp.org.

Agarwal, Sumit, John C. Driscoll, Xavier Gabaix, and David Laibson. (2009). "The Age of Reason: Financial Decisions over the Life-cycle with Implications for Regulation.” Brookings Papers on Economic Activity Fall, 51-117.

Agarwal, Sumit and Douglas D. Evanoff. (2013). "Loan Product Steering in Mortgage Market." Available at SSRN: http://dx.doi.org/10.2139/ssrn.2204400.

Bertrand, Marianne, Dean Karlan, Sendhil Mullainathan, Eldar Shafir, and Jonathan Zinman. (2010). "What's Advertising Content Worth? Evidence from a Consumer Credit Marketing Field Experiment.” Quarterly Journal of Economics 125(1), 263-305.

Bricker, Jesse, Lisa J. Dettling, Alice Henriques, Joanne W. Hsu, Kevin B. Moore, John Sabelhaus, Jeffrey Thompson, and Richard A. Windle. (2014). "Changes in U.S. Family Finances from 2010 to 2013: Evidence from the Survey of Consumer Finances.” Federal Reserve Bulletin 100(4), 1-41.

Bucks, Brian, K., Arthur B. Kennickell, Traci L. Mach, and Kevin B. Moore. (2009). “Changes in U.S. Family Finances from 2004 to 2007: Evidence from the Survey of Consumer Finances.” Federal Reserve Bulletin 95, A1-A55.

Butrica, Barbara, A., and Nadia S. Karamcheva. (2013). "Does Household Debt Influence the Labor Supply and Benefit Claiming Decisions of Older Americans?” Working Paper 22. Urban Institute. 
Cecchetti, Stephen G., Madhusudan Mohanty, and Fabrizio Zampolli. (2011). "The Real Effects of Debt.” BIS Working Papers 352.

Chai, Jingjing, Wolfram Horneff, Raimond Maurer, and Olivia S. Mitchell. (2011). “Optimal Portfolio Choice over the Life Cycle with Flexible Work, Endogenous Retirement, and Lifetime Payouts.” Review of Finance 15(4), 875-907.

Cho, Hanah. (2012). "Seniors Grow Old Under Debt.” The Baltimore Sun/New America Media, May 29. http://newamericamedia.org/2012/05/seniors-grow-old-under-debt.php.

Christelis, Dimitris, Michael Ehrmann, and Dimitris Georgarakos. (2015). “Exploring Differences in Household Debt Across Euro Area Countries and the US." Bank of Canada Working Paper 2015-16.

Copeland, Craig. (2013). "Debt of the Elderly and Near Elderly, 1992-2010.” EBRI Notes. February 34(2), 2-15.

Debelle, Guy. (2004). “Macroeconomic Implications of Rising Household Debt.” BIS Working Papers 153.

Delavande, Adeline, Susann Rohwedder, and Robert Willis. (2008). "Preparation for Retirement, Financial Literacy and Cognitive Resources.” MRRC Working Paper 2008-190.

Derousseau, Ryan. (2016). "3 Ways to Reduce Debt as You Near Retirement.” U.S. News, March 25. http://money.usnews.com/investing/articles/2016-03-25/3-ways-to-reducedebt-as-you-near-retirement.

Dynan, Karen E. (2009). “Changing Household Financial Opportunities and Economic Security." Journal of Economic Perspectives 23(4), 49-68. 
Dynan, Karen E., and Donald L. Kohn. (2007). "The Rise in U.S. Household Indebtedness: Causes and Consequences." Finance and Economics Discussion Series Divisions of Research \& Statistics and Monetary Affairs. Federal Reserve Board Working Paper 37, $1-36$.

Edelberg, Wendy. (2006). "Risk-Based Pricing of Interest Rates for Consumer Loans.” Journal of Monetary Economics 53(8), 2283-2298.

Federal Reserve Bank of New York. (2016). "Quarterly Report on Household Debt and Credit." https://www.newyorkfed.org/medialibrary/interactives/householdcredit/data/pdf/HHDC_ 2016Q1.pdf.

Federal Reserve Bank of New York. (2017). "Quarterly Report on Household Debt and Credit.” https://www.newyorkfed.org/medialibrary/interactives/householdcredit/data/pdf/HHDC_ 2016Q4.pdf.

Gabaix, Xavier, and David Laibson. (2006). "Shrouded Attributes, Consumer Myopia, and Information Suppression in Competitive Markets.” Quarterly Journal of Economics 121(2), 505-540.

Gine, Xavier, Cristina Martinez Cuellar, and Rafael Keenan Mazer. (2014). "Financial (Dis-) Information: Evidence from an Audit Study in Mexico.” World Bank Policy Research Working Paper 6902.

Gurun, Umit, G., Gregor Matvos, and Amit Seru. (2016). “Advertising Expensive Mortgages.” The Journal of Finance 71(5), 2371-2416. 
Helman, Ruth, Craig Copeland, and Jack VanDerhei. (2015). “The 2015 Retirement Confidence Survey: Having a Retirement Savings Plan a Key Factor in Americans' Retirement Confidence.” EBRI Issue Brief 413, April 2015.

Hurd, Michael D. (1990). "Research on the Elderly: Economic Status, Retirement, Consumption, and Saving," Journal of Economic Literature 28(2), 565-637.

Hurst, Erik, and Frank P. Stafford. (2004). "Home is Where the Equity Is: Mortgage Refinancing and Household Consumption." Journal of Money, Credit, and Banking 36(6), 985-1014.

Hyytinen, Ari, and Hanna Putkuri. Forthcoming. "Household Optimism and Overborrowing." Journal of Money, Credit, and Banking.

Kumhof, Michael, Romain Rancière, and Pablo Winant. (2015). “Inequality, Leverage, and Crises.” American Economic Review 105(3), 1217-45.

Lu, Timothy, Olivia S. Mitchell, Stephen P. Utkus, and Jean A. Young. (2017). "Borrowing from the Future: 401(k) Plan Loans and Loan Defaults.” National Tax Journal 70(1), 77-110.

Lusardi, Annamaria. (2011). “Americans’ Financial Capability.” NBER Working Paper 17103.

Lusardi, Annamaria, and Carlo de Bassa Scheresberg. (2013). "Financial Literacy and High-Cost Borrowing in the United States.” NBER Working Paper 18969.

Lusardi, Annamaria, Pierre-Carl Michaud, and Olivia S. Mitchell. (2017). “Optimal Financial Literacy and Wealth Inequality.” Journal of Political Economy 125 (2), 431-477.

Lusardi, Annamaria, and Olivia S. Mitchell. (2007). "Baby Boomer Retirement Security: The Roles of Planning, Financial Literacy and Housing Wealth.” Journal of Monetary Economics 54(1), 205-224. 
Lusardi, Annamaria, and Olivia S. Mitchell. (2008). "Planning and Financial Literacy: How Do Women Fare?” American Economic Review 98(2), 413-417.

Lusardi, Annamaria, and Olivia S. Mitchell. (2009). "How Ordinary Consumers Make Complex Economic Decisions: Financial Literacy and Retirement Readiness.” NBER Working Paper 15350.

Lusardi, Annamaria, and Olivia S. Mitchell. (2011a). “The Outlook for Financial Literacy.” In Financial Literacy: Implications for Retirement Security and the Financial Marketplace, edited by Olivia S. Mitchell and Annamaria Lusardi, pp. 1-13. Oxford, UK: Oxford University Press.

Lusardi, Annamaria, and Olivia S. Mitchell. (2011b). "Financial Literacy and Planning: Implications for Retirement Wellbeing.” In Financial Literacy: Implications for Retirement Security and the Financial Marketplace edited by Olivia S. Mitchell and Annamaria Lusardi, pp. 17-39. Oxford, UK: Oxford University Press.

Lusardi, Annamaria, and Olivia S. Mitchell. (2011c). "Financial Literacy and Retirement Planning in the United States.” Journal of Pension Economics and Finance 10(4), 509525.

Lusardi, Annamaria, and Olivia S. Mitchell. (2013). "Debt and Debt Management among Older Adults.” GFLEC Working Paper 2013-2.

Lusardi, Annamaria, and Olivia S. Mitchell. (2014). “The Economic Importance of Financial Literacy: Theory and Evidence.” Journal of Economic Literature 52(1), 5-44.

Lusardi, Annamaria, and Olivia S. Mitchell. (2016). “Older Women’s Labor Market Attachment, Retirement Planning, and Household Debt." GFLEC Working Paper 2016-3. 
Lusardi, Annamaria, Olivia S. Mitchell, and Vilsa Curto. (2014). "Financial Literacy and Financial Sophistication among the Older Population.” Journal of Pension Economics and Finance 13(4), 347-366.

Lusardi, Annamaria, Daniel J. Schneider, and Peter Tufano. (2011). "Financially Fragile Households: Evidence and Implications.” Brookings Papers on Economic Activity Spring, 83-134.

Lusardi, Annamaria, and Peter Tufano. (2009). "Teach Workers about the Peril of Debt." Harvard Business Review 87(11), 22-24.

Lusardi, Annamaria, and Peter Tufano. (2015). “Debt Literacy, Financial Experiences, and Overindebtedness.” Journal of Pension Economics and Finance 14(4), 332-368.

Mayer, Christopher. Forthcoming. "Housing, Mortgages, and Retirement." In Evidence and Innovation in Housing Law and Policy, edited by Lee Fennell and Benjamin Keys. New York: Cambridge University Press.

Mian, Atif, and Amir Sufi. (2011). "House Prices, Home Equity-Based Borrowing, and the US Household Leverage Crisis.” American Economic Review 101(5), 2132-2156.

Pham, Sherisse. (2011). "Retirements Swallowed by Debt.” New York Times, January 26. newoldage.blogs.nytimes.com/2011/01/26/retirements-swallowed-by-debt/.

Pottow, John A.E. (2012). “The Rise in Elder Bankruptcy Filings and Failure of U.S. Bankruptcy Law.” The Elder Law Journal 19(1), 119-157.

Schmidt, Sebastian. (2013). "Optimal Monetary and Fiscal Policy with a Zero Bound on Nominal Interest Rates.” Journal of Money, Credit, and Banking 45(7), 1335-1350. 
Securian Financial Group. (2013). Retirement Time Bomb: Mortgage Debt. Securian Investments. Www.securiannews.com/sites/securian.newshq.businesswire.com/files/research/file/RetD ebtSummary-Apr2013-F78685-1_pod.pdf.

Utkus, Stephen P., and Jean A. Young. (2011). "Financial Literacy and 401(k) Loans.” In Financial Literacy: Implications for Retirement Security and the Financial Marketplace, edited by Olivia S. Mitchell and Annamaria Lusardi, pp. 59-75. Oxford, UK: Oxford University Press.

Venti, Steven F., and David A. Wise. (1990). “But They Don't Want to Reduce Housing Equity.” In Issues in the Economics of Aging. Edited by David A. Wise, pp. 13-32. Chicago: University of Chicago Press.

Venti, Steven, and David A. Wise. (1991). “Aging and the Income Value of Housing Wealth.” Journal of Public Economics 44(3), 371-397.

Vornovytskyy, Marina, Alfred Gottschalck, and Adam Smith. (2011). "Household Debt in the U.S.: 2000 to 2011." https://www.census.gov/people/wealth/files/Debt\%20Highlights\%202011.pdf. 
Table 1. Levels and Distribution of Cohort Total Debt and Debt Components in the Health and Retirement Study (HRS).

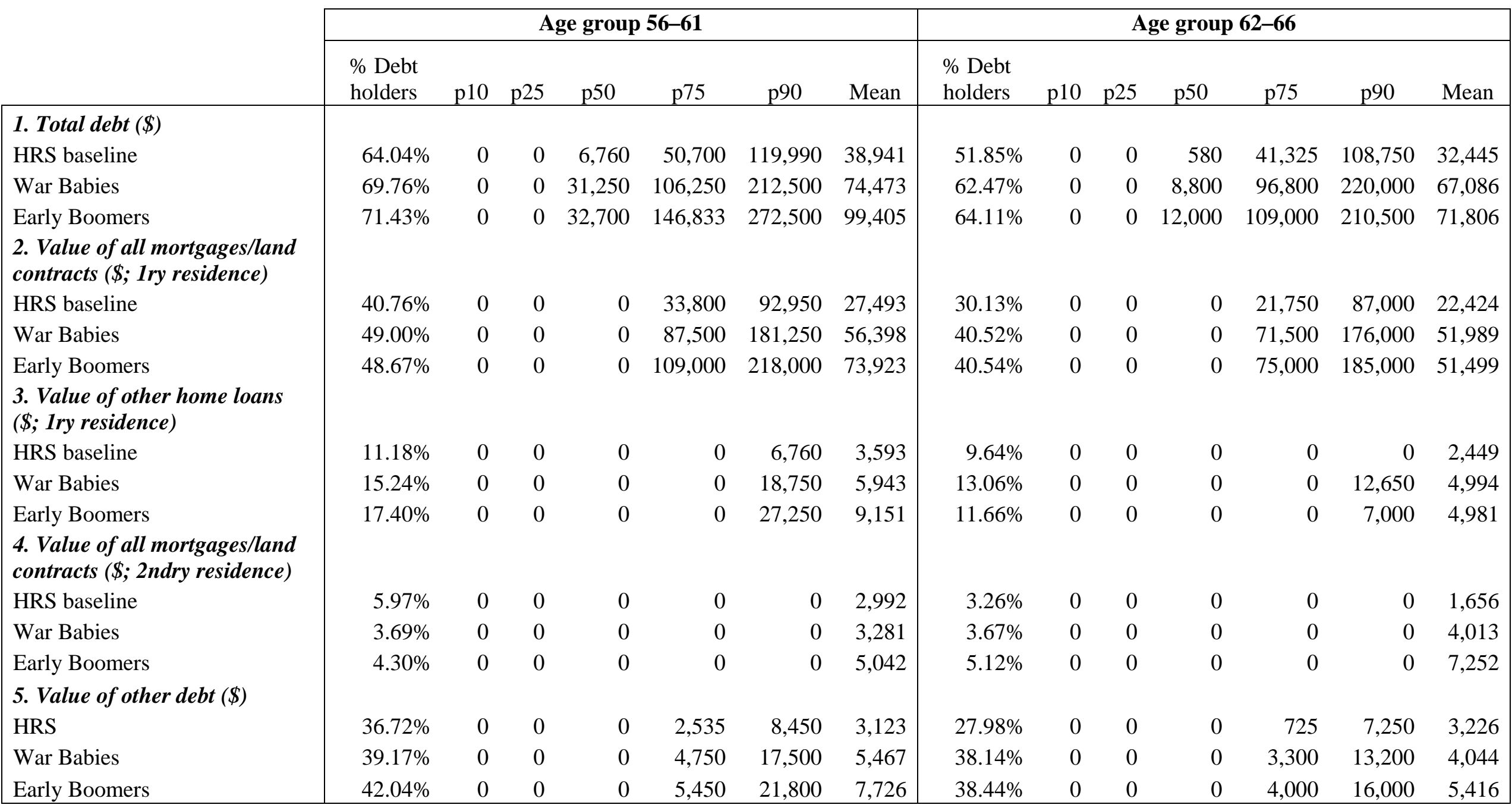

Note: The sample includes all age-eligible individuals age 56-61 and 62-66 in the cohort indicated. For 56-61 age group, the HRS baseline cohort was observed in 1992; the War Babies in 2004; and the Early Boomers in 2010. For 62-66 age group, the HRS baseline cohort was observed in 1998; the War Babies in 2008; and the Early Boomers in 2014. Total debt includes the value of mortgages and other loans on the household's primary residence, other mortgages, and other debt (including credit card debt, medical debt, etc.). All dollar values in 2015 dollars. Data are weighted. 
Table 2. Levels and Distribution of Cohort Total Debt Ratios and Debt Ratio Components (HRS).

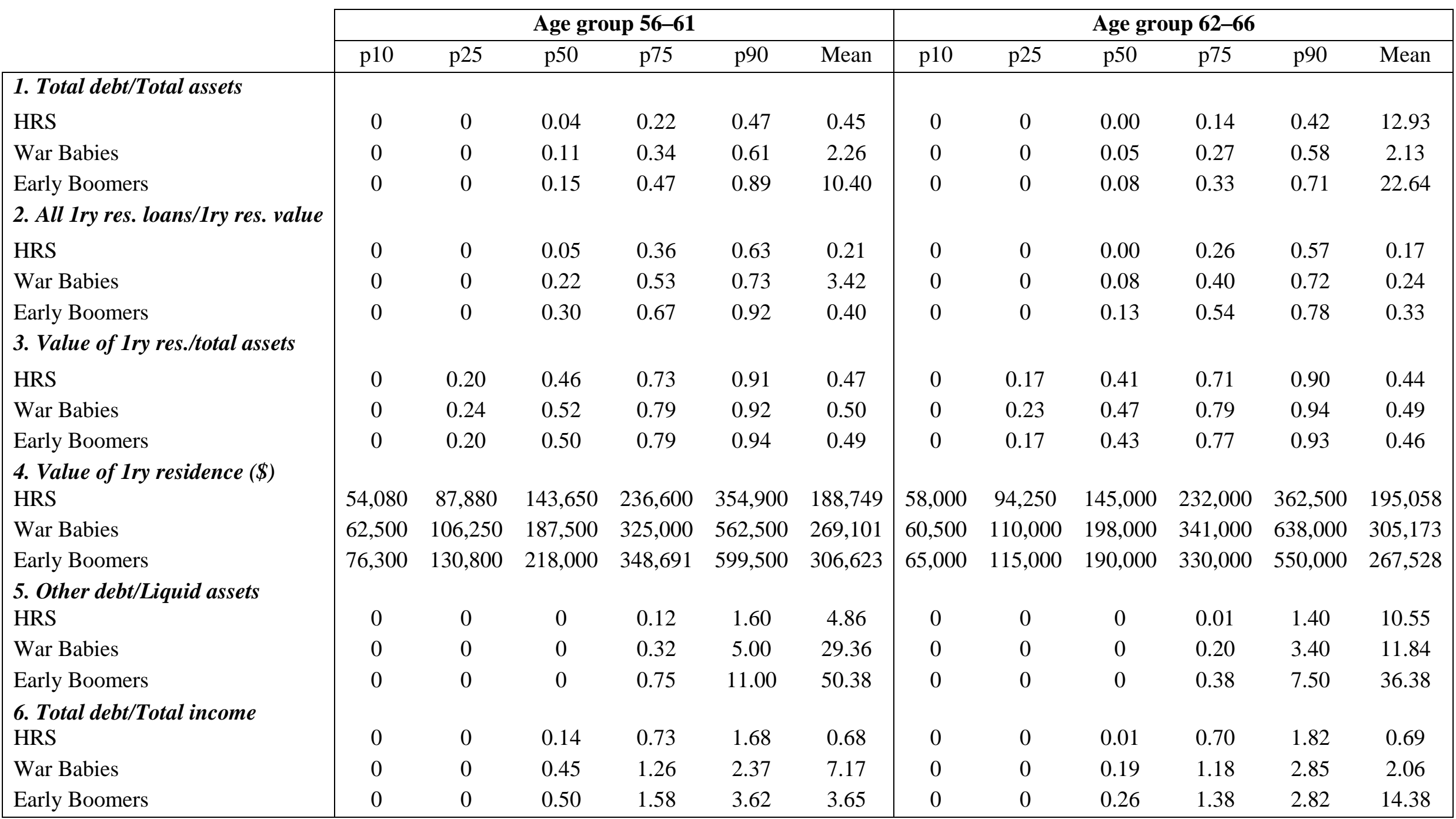

Note: Total assets include all checking and savings accounts, CDs, money market funds, T-bills, bonds/bond funds, stocks/stock market funds, IRAs, 401(k)s and Keoghs, the value of primary residence and other real estate, vehicles, business equity, and other savings. Housing debt includes home mortgages and other home loans. Liquid assets are defined as the sum of checking and savings accounts, CDs, money market funds, T-bills, bonds/bond funds, and stocks/stock market funds. See also notes to Table 1. 
Table 3. Levels of Cohort Total Debt/Asset Ratios, and Debt Component/Asset Ratios (HRS).

\begin{tabular}{|l|c|c|}
\cline { 2 - 3 } \multicolumn{1}{c|}{} & Age group 56-61 & Age group 62-66 \\
\cline { 2 - 3 } \multicolumn{1}{c|}{ 1. Total debt/Total assets $>\mathbf{0 . 5}$} & \% in the sample & $\%$ in the sample \\
HRS & & \\
War Babies & $8.73 \%$ & $8.00 \%$ \\
Early Boomers & $15.36 \%$ & $12.85 \%$ \\
2. All 1ry res. loans/1ry res. value $>\mathbf{0 . 5}$ & $22.49 \%$ & $16.55 \%$ \\
HRS & & \\
War Babies & $16.23 \%$ & $12.99 \%$ \\
Early Boomers & $25.68 \%$ & $19.75 \%$ \\
3. Other debt/Liquid assets $>\mathbf{0 . 5}$ & $34.60 \%$ & $27.18 \%$ \\
HRS & & \\
War Babies & $16.56 \%$ & $13.51 \%$ \\
Early Boomers & $22.16 \%$ & $21.29 \%$ \\
4. Respondents with $<\$ 25 K$ in savings & $27.32 \%$ & $23.13 \%$ \\
HRS & & \\
War Babies & $14.63 \%$ & $14.19 \%$ \\
Early Boomers & $16.03 \%$ & $15.71 \%$ \\
\hline
\end{tabular}

Note: See notes to Tables 1 and 2. 
Table 4. Multivariate Analysis of the Factors Associated with Financial Vulnerability (HRS).

\begin{tabular}{|c|c|c|c|c|c|c|c|c|c|c|c|c|c|c|c|c|}
\hline \multirow[b]{3}{*}{ W } & \multicolumn{8}{|c|}{ Age group 56-61 } & \multicolumn{8}{|c|}{ Age group 62-66 } \\
\hline & \multicolumn{2}{|c|}{$\begin{array}{l}\text { Tot. debt/Tot. } \\
\text { assets }>0.5\end{array}$} & \multicolumn{2}{|c|}{$\begin{array}{l}\text { 1ry res. } \\
\text { debt/asset }>0.5\end{array}$} & \multicolumn{2}{|l|}{$\begin{array}{l}\text { Other } \\
\text { debt/Liquid } \\
\text { assets }>0.5\end{array}$} & \multicolumn{2}{|c|}{$\begin{array}{l}\text { Total net } \\
\text { wealth }<\$ 25 \mathrm{~K}\end{array}$} & \multicolumn{2}{|c|}{$\begin{array}{l}\text { Tot. debt/Tot. } \\
\text { assets }>0.5\end{array}$} & \multicolumn{2}{|c|}{$\begin{array}{l}\text { 1ry res. } \\
\text { debt/asset }>0.5\end{array}$} & \multicolumn{2}{|l|}{$\begin{array}{l}\text { Other } \\
\text { debt/Liquid } \\
\text { assets }>0.5\end{array}$} & \multicolumn{2}{|c|}{$\begin{array}{l}\text { Total net } \\
\text { wealth }<\$ 25 \mathrm{~K}\end{array}$} \\
\hline & 0.073 & $* *$ & 0.098 & $* *$ & 0.074 & $* *$ & 0.035 & $* *$ & 0.052 & $* *$ & 0.069 & $* *$ & 0.093 & $* *$ & 0.030 & $*$ \\
\hline & $(0.012)$ & & $(0.017)$ & & $(0.015)$ & & $(0.011)$ & & $(0.014)$ & & $(0.018)$ & & $(0.018)$ & & $(0.013)$ & \\
\hline \multirow[t]{2}{*}{ Early Boomers } & 0.150 & $* *$ & 0.195 & $* *$ & 0.140 & $* *$ & 0.127 & $* *$ & 0.094 & $* *$ & 0.147 & $* *$ & 0.122 & $* *$ & 0.098 & $* *$ \\
\hline & $(0.013)$ & & $(0.018)$ & & $(0.016)$ & & $(0.012)$ & & $(0.014)$ & & $(0.020)$ & & $(0.018)$ & & $(0.013)$ & \\
\hline \multirow[t]{2}{*}{ Age } & -0.013 & $* *$ & -0.020 & $* *$ & -0.014 & $* *$ & -0.010 & $* *$ & -0.004 & & -0.005 & & 0.002 & & 0.000 & \\
\hline & $(0.003)$ & & $(0.004)$ & & $(0.004)$ & & $(0.003)$ & & $(0.004)$ & & $(0.006)$ & & $(0.005)$ & & $(0.004)$ & \\
\hline \multirow[t]{2}{*}{ Married } & -0.047 & $* *$ & -0.016 & & -0.015 & & -0.210 & $* *$ & -0.030 & $*$ & -0.004 & & -0.012 & & -0.227 & $* *$ \\
\hline & $(0.014)$ & & $(0.019)$ & & $(0.017)$ & & $(0.014)$ & & $(0.014)$ & & $(0.020)$ & & $(0.018)$ & & $(0.015)$ & \\
\hline \multirow[t]{2}{*}{ Male } & 0.010 & & 0.032 & $* *$ & 0.011 & & 0.021 & $*$ & 0.002 & & 0.008 & & -0.003 & & 0.007 & \\
\hline & $(0.009)$ & & $(0.011)$ & & $(0.010)$ & & $(0.009)$ & & $(0.010)$ & & $(0.013)$ & & $(0.013)$ & & $(0.011)$ & \\
\hline \multirow[t]{2}{*}{ Number of children } & 0.010 & $* *$ & 0.023 & $* *$ & 0.015 & $* *$ & 0.015 & $* *$ & 0.006 & & 0.014 & $* *$ & 0.012 & $* *$ & 0.011 & $* *$ \\
\hline & $(0.003)$ & & $(0.004)$ & & $(0.004)$ & & $(0.003)$ & & $(0.003)$ & & $(0.005)$ & & $(0.004)$ & & $(0.003)$ & \\
\hline \multirow[t]{2}{*}{ White } & -0.064 & $* *$ & -0.025 & & -0.075 & $* *$ & -0.134 & $* *$ & -0.048 & $* *$ & -0.008 & & -0.056 & $*$ & -0.130 & $* *$ \\
\hline & $(0.016)$ & & $(0.020)$ & & $(0.020)$ & & $(0.015)$ & & $(0.018)$ & & $(0.022)$ & & $(0.023)$ & & $(0.017)$ & \\
\hline \multirow[t]{2}{*}{ High school } & -0.006 & & 0.018 & & -0.033 & & -0.119 & $* *$ & -0.002 & & 0.013 & & 0.006 & & -0.107 & $* *$ \\
\hline & $(0.015)$ & & $(0.018)$ & & $(0.019)$ & & $(0.015)$ & & $(0.017)$ & & $(0.021)$ & & $(0.022)$ & & $(0.018)$ & \\
\hline \multirow[t]{2}{*}{ Some college } & -0.011 & & 0.027 & & -0.062 & $* *$ & -0.164 & $* *$ & -0.030 & & 0.014 & & -0.027 & & -0.161 & $* *$ \\
\hline & $(0.018)$ & & $(0.023)$ & & $(0.022)$ & & $(0.017)$ & & $(0.020)$ & & $(0.026)$ & & $(0.025)$ & & $(0.020)$ & \\
\hline \multirow[t]{2}{*}{ College or more } & -0.018 & & 0.066 & $*$ & -0.047 & & -0.191 & $* *$ & -0.005 & & 0.062 & $*$ & -0.040 & & -0.171 & $* *$ \\
\hline & $(0.021)$ & & $(0.029)$ & & $(0.026)$ & & $(0.019)$ & & $(0.024)$ & & $(0.031)$ & & $(0.029)$ & & $(0.022)$ & \\
\hline \multirow[t]{2}{*}{ Household income $(\$ 10 \mathrm{k})$} & -0.002 & $* *$ & 0.001 & & -0.004 & $* *$ & -0.003 & $* *$ & -0.001 & $* *$ & 0.000 & & -0.001 & $* *$ & -0.001 & $* *$ \\
\hline & 0.000 & & $(0.001)$ & & $(0.001)$ & & $(0.001)$ & & 0.000 & & $(0.001)$ & & $(0.001)$ & & 0.000 & \\
\hline \multirow[t]{2}{*}{ Poor health } & 0.060 & $* *$ & 0.010 & & 0.105 & $* *$ & 0.150 & $* *$ & 0.095 & $* *$ & 0.038 & & 0.167 & $* *$ & 0.156 & $* *$ \\
\hline & $(0.015)$ & & $(0.018)$ & & $(0.018)$ & & $(0.014)$ & & $(0.016)$ & & $(0.020)$ & & $(0.021)$ & & $(0.017)$ & \\
\hline \multirow[t]{2}{*}{ Constant } & 0.896 & $* *$ & 1.235 & $* *$ & 1.025 & $* *$ & 1.047 & $* *$ & 0.392 & & 0.400 & & 0.041 & & 0.446 & \\
\hline & $(0.186)$ & & $(0.250)$ & & $(0.224)$ & & $(0.165)$ & & $(0.258)$ & & $(0.377)$ & & $(0.338)$ & & $(0.252)$ & \\
\hline $\mathrm{N}$ & 8,533 & & 7,080 & & 7,339 & & 9,077 & & 5,982 & & 4,984 & & 5,141 & & 6,327 & \\
\hline R-squared & 0.051 & & 0.044 & & 0.055 & & 0.245 & & 0.043 & & 0.027 & & 0.061 & & 0.238 & \\
\hline
\end{tabular}

Notes: Coefficient estimates from OLS regression, standard errors in parentheses. See Table 2 for definitions of dependent variables. Explanatory variables include age, an indicator of being married, male, number of children, white, 3 educational attainment categories (high school, some college, college degree with reference category high school dropout), total household income (in 000), and an indicator of poor health. See also notes to Tables 1 and 2 . Data weighted. ** p<0.01, * $\mathrm{p}<0.05$ 
Table 5. Level and Composition of Self-Reported Household Debt and Debt Concerns (NFCS).

\begin{tabular}{|c|c|c|c|c|}
\hline & \multicolumn{2}{|c|}{ Age group 56-61 } & \multicolumn{2}{|c|}{ Age group 62-66 } \\
\hline & 2012 & 2015 & 2012 & 2015 \\
\hline \multicolumn{5}{|l|}{ Mortgage debt } \\
\hline Underwater with home value $^{\text {a }}$ & $16.7 \%$ & $8.9 \%$ & $12.2 \%$ & $8.9 \%$ \\
\hline Late with mortgage payments, at least once ${ }^{a}$ & $16.2 \%$ & $10.6 \%$ & $10.6 \%$ & $6.0 \%$ \\
\hline Foreclosure process on their home ${ }^{a}$ & $2.6 \%$ & N/A & $1.7 \%$ & N/A \\
\hline \multicolumn{5}{|l|}{ Other types of debt } \\
\hline Credit card debt ${ }^{\mathrm{a}}$ & $52.4 \%$ & $46.5 \%$ & $43.0 \%$ & $40.6 \%$ \\
\hline Credit card fees, at least one type ${ }^{a}$ & $36.7 \%$ & $30.3 \%$ & $25.4 \%$ & $22.7 \%$ \\
\hline Unpaid medical bills & $23.4 \%$ & $20.2 \%$ & $15.4 \%$ & $14.7 \%$ \\
\hline High-cost borrowing ${ }^{b}$ & $19.8 \%$ & $19.4 \%$ & $13.1 \%$ & $11.5 \%$ \\
\hline Student loan ${ }^{\mathrm{c}}$ & $9.6 \%$ & $14.0 \%$ & $5.5 \%$ & $7.9 \%$ \\
\hline \multicolumn{5}{|l|}{ Borrowing from retirement accounts } \\
\hline Loan from retirement accounts ${ }^{a}$ & $7.0 \%$ & $5.8 \%$ & $4.5 \%$ & $6.3 \%$ \\
\hline Hardship withdrawal from retirement accounts ${ }^{a}$ & $5.7 \%$ & $4.9 \%$ & $3.1 \%$ & $3.9 \%$ \\
\hline \multicolumn{5}{|l|}{ Indicators of financial vulnerability } \\
\hline Too much debt & $39.9 \%$ & $36.5 \%$ & $27.7 \%$ & $26.4 \%$ \\
\hline Cannot come up with $\$ 2,000$ & $35.5 \%$ & $32.8 \%$ & $22.9 \%$ & $23.3 \%$ \\
\hline $\mathrm{N}$ & 2,983 & 2,942 & 2,567 & 2,851 \\
\hline
\end{tabular}

Note: The sample includes all age-eligible individuals age 56-61 and 62-66. Statistics weighted using sample weights.

${ }^{a}$ Values conditional on holding the asset or debt.

${ }^{\mathrm{b}}$ High-cost borrowing refers to the use of alternative financial services, such as payday loans, pawnshops, rent-to-own products, and auto title loans.

${ }^{c}$ Direct comparisons between the statistics for 2012 and 2015 are not possible because the question was asked differently.

Table 6. Self-Reported Financial Behaviors and Perceptions (NFCS).

\begin{tabular}{|c|c|c|c|c|}
\hline & \multicolumn{2}{|c|}{ Age group 56-61 } & \multicolumn{2}{|c|}{ Age group 62-66 } \\
\hline & 2012 & 2015 & 2012 & 2015 \\
\hline Propensity to save & & & & \\
\hline Spending less than income & $44.2 \%$ & $41.0 \%$ & $46.2 \%$ & $45.7 \%$ \\
\hline Planning for retirement & & & & \\
\hline Figure out how much to save for retirement & $47.1 \%$ & $44.3 \%$ & $55.4 \%$ & $55.2 \%$ \\
\hline Additional measure of potential financial problems & & & & \\
\hline Worry about running out of money in retirement & N/A & $56.8 \%$ & N/A & $47.3 \%$ \\
\hline $\mathrm{N}$ & 2,983 & 2,942 & 2,567 & 2,851 \\
\hline
\end{tabular}

Note: The sample includes all age-eligible individuals 56-61 and 62-66. Statistics weighted using sample weights. 
Table 7. Multivariate Regression Model of Self-Assessed Debt (2012 and 2015 NFCS).

Age group 56-61

Self-assessed debt
Age group 62-66

Self-assessed debt

\begin{tabular}{|c|c|c|}
\hline Age & $\begin{array}{c}-0.074 * * \\
(0.019)\end{array}$ & $\begin{array}{c}-0.085^{* *} \\
(0.024)\end{array}$ \\
\hline Single & $\begin{array}{c}0.020 \\
(0.107)\end{array}$ & $\begin{array}{c}0.039 \\
(0.134)\end{array}$ \\
\hline Separated or divorced & $\begin{array}{c}0.004 \\
(0.093)\end{array}$ & $\begin{array}{c}0.176^{*} \\
(0.102)\end{array}$ \\
\hline Widow & $\begin{array}{c}0.082 \\
(0.151)\end{array}$ & $\begin{array}{c}-0.021 \\
(0.126)\end{array}$ \\
\hline Male & $\begin{array}{c}0.007 \\
(0.067)\end{array}$ & $\begin{array}{c}0.236 * * \\
(0.069)\end{array}$ \\
\hline Number of dependent children & $\begin{array}{c}0.197 * * \\
(0.043)\end{array}$ & $\begin{array}{c}0.346 * * \\
(0.063)\end{array}$ \\
\hline Afro-American & $\begin{array}{c}0.184 \\
(0.102)\end{array}$ & $\begin{array}{c}0.590 * * \\
(0.128)\end{array}$ \\
\hline Hispanic & $\begin{array}{l}-0.059 \\
(0.149)\end{array}$ & $\begin{array}{c}-0.028 \\
(0.174)\end{array}$ \\
\hline Asian & $\begin{array}{l}-0.321 \\
(0.181)\end{array}$ & $\begin{array}{c}-0.238 \\
(0.200)\end{array}$ \\
\hline Others & $\begin{array}{l}-0.034 \\
(0.193)\end{array}$ & $\begin{array}{c}0.223 \\
(0.206)\end{array}$ \\
\hline High school & $\begin{array}{c}0.045 \\
(0.184)\end{array}$ & $\begin{array}{l}-0.265 \\
(0.235)\end{array}$ \\
\hline Some college & $\begin{array}{c}0.060 \\
(0.184)\end{array}$ & $\begin{array}{c}-0.097 \\
(0.236)\end{array}$ \\
\hline College or more & $\begin{array}{c}-0.081 \\
(0.191)\end{array}$ & $\begin{array}{l}-0.299 \\
(0.240)\end{array}$ \\
\hline Income $\$ 15-25 \mathrm{~K}$ & $\begin{array}{l}-0.003 \\
(0.143)\end{array}$ & $\begin{array}{c}0.141 \\
(0.165)\end{array}$ \\
\hline Income $\$ 25-35 \mathrm{~K}$ & $\begin{array}{l}-0.138 \\
(0.151)\end{array}$ & $\begin{array}{c}0.048 \\
(0.172)\end{array}$ \\
\hline Income $\$ 35-50 \mathrm{~K}$ & $\begin{array}{l}-0.205 \\
(0.141)\end{array}$ & $\begin{array}{c}-0.136 \\
(0.165)\end{array}$ \\
\hline Income $\$ 50-75 \mathrm{~K}$ & $\begin{array}{c}-0.459 * * \\
(0.141)\end{array}$ & $\begin{array}{c}-0.522 * * \\
(0.162)\end{array}$ \\
\hline Income $\$ 75-100 \mathrm{~K}$ & $\begin{array}{c}-0.697 * * \\
(0.156)\end{array}$ & $\begin{array}{c}-0.756 * * \\
(0.172)\end{array}$ \\
\hline Income $\$ 100-150 \mathrm{~K}$ & $\begin{array}{c}-0.780 * * \\
(0.159)\end{array}$ & $\begin{array}{c}-0.649 * * \\
(0.181)\end{array}$ \\
\hline Income $\$ 150 \mathrm{~K}+$ & $\begin{array}{c}-1.371 * * \\
(0.170)\end{array}$ & $\begin{array}{c}-0.956 * * \\
(0.202)\end{array}$ \\
\hline Income shock & $\begin{array}{c}0.863 * * \\
(0.079)\end{array}$ & $\begin{array}{l}1.122 * * \\
(0.094)\end{array}$ \\
\hline FinLit index & $\begin{array}{c}-0.088^{* *} * \\
(0.026)\end{array}$ & $\begin{array}{c}-0.092 * * \\
(0.029)\end{array}$ \\
\hline
\end{tabular}


Year 2015

Constant
$-0.239 * *$

(0.065)

8.559**
-0.167 *

(0.067)

9.152**

(1.550)

$\mathrm{N}$

5,852

5,107

R-squared

0.100

0.132

Note: The sample includes all age-eligible individuals 56-61 and 62-66 in the 2012 and 2015 NFCS; estimates weighted using sample weights. The dependent variable is the response to the following question: "How strongly do you agree or disagree with the following statement? "I have too much debt right now." Values range from 1 to 7 , where 1 means "I strongly disagree" and 7 means "I strongly agree." Mean value of the dependent variable Self-assessed Debt is 3.78 for the 56-61 age group and 3.18 for the 62-66 age group. FinLit index is constructed as the number of correct answers to the five financial literacy questions. Including FinLit index among the regressors does not change much the estimate and significance of the other variables. Robust standard errors in parentheses. ${ }^{* *} \mathrm{p}<0.01,{ }^{*} \mathrm{p}<0.05$ 
Table 8. Multivariate Regression Model of Financial Fragility (2012 and 2015 NFCS).

Age group 56-61

Financial fragility
Age group 62-66

Financial fragility
Age

Single

Separated or divorced

Widow

Male

Number of dependent children

Afro-American

Hispanic

Asian

Others

High school

Some college

College or more

Income $\$ 15-25 \mathrm{~K}$

Income $\$ 25-35 \mathrm{~K}$

Income $\$ 35-50 \mathrm{~K}$

Income $\$ 50-75 \mathrm{~K}$

Income \$75-100K

Income $\$ 100-150 \mathrm{~K}$

Income $\$ 150 \mathrm{~K}+$

Income shock

FinLit index
$-0.007$

$(0.004)$

0.001

$(0.021)$

$-0.011$

(0.019)

$-0.024$

(0.031)

$-0.026 *$

(0.013)

0.021 *

(0.009)

0.117 **

(0.021)

0.052

(0.031)

$-0.028$

(0.032)

$0.087^{*}$

(0.034)

$-0.105 * *$

(0.034)

$-0.111^{* *}$

(0.035)

$-0.138 * *$

(0.036)

$-0.153^{* *}$

(0.028)

$-0.255^{* *}$

(0.031)

$-0.374 * *$

(0.028)

$-0.474 * *$

(0.028)

$-0.550 * *$

$(0.028)$

$-0.625^{* *}$

(0.027)

$-0.620 * *$

(0.029)

$0.149 * *$

(0.016)

$-0.037 * *$

(0.005)
$-0.008$

(0.004)

0.034

(0.027)

0.024

(0.020)

0.035

(0.025)

0.018

(0.012)

0.016

(0.011)

$0.155^{* *}$

(0.028)

$0.065^{*}$

(0.032)

$-0.018$

(0.029)

0.043

(0.038)

$-0.105^{*}$

(0.047)

$-0.115^{*}$

(0.047)

$-0.153 * *$

(0.048)

$-0.188^{* *}$

(0.035)

$-0.327 * *$

(0.036)

$-0.433 * *$

(0.034)

$-0.538 * *$

(0.032)

$-0.571 * *$

(0.032)

$-0.579 * *$

(0.033)

$-0.577 * *$

(0.033)

$0.137 * *$

(0.018)

$-0.034 * *$

(0.006) 
Year 2015

Constant

Observations

5,715

4,991

R-squared

0.313

0.333

Note: The sample includes all age-eligible individuals 56-61 and 62-66 in the 2012 and 2015 NFCS; estimates weighted using sample weights. The dependent variable is a dummy variable response to the following question: "How confident are you that you could come up with $\$ 2,000$ if an unexpected need arose within the next month?" Outcome coded as 1 for those who certain or probably could not come up with $\$ 2,000$ and 0 for those who certain or probably could come up with $\$ 2,000$. Mean value of the dependent variable Financial Fragility is 0.35 for the 56-61 age group and 0.24 for the 62-66 age group. FinLit index is constructed as the number of correct answers to the five financial literacy questions. Including FinLit index among the regressors does not change much the estimate and significance of the other variables. Robust standard errors in parentheses. $* * \mathrm{p}<0.01, * \mathrm{p}<0.05$ 
Figure 1. The Evolution of Self-Assessed Debt and Financial Fragility over the Life Cycle
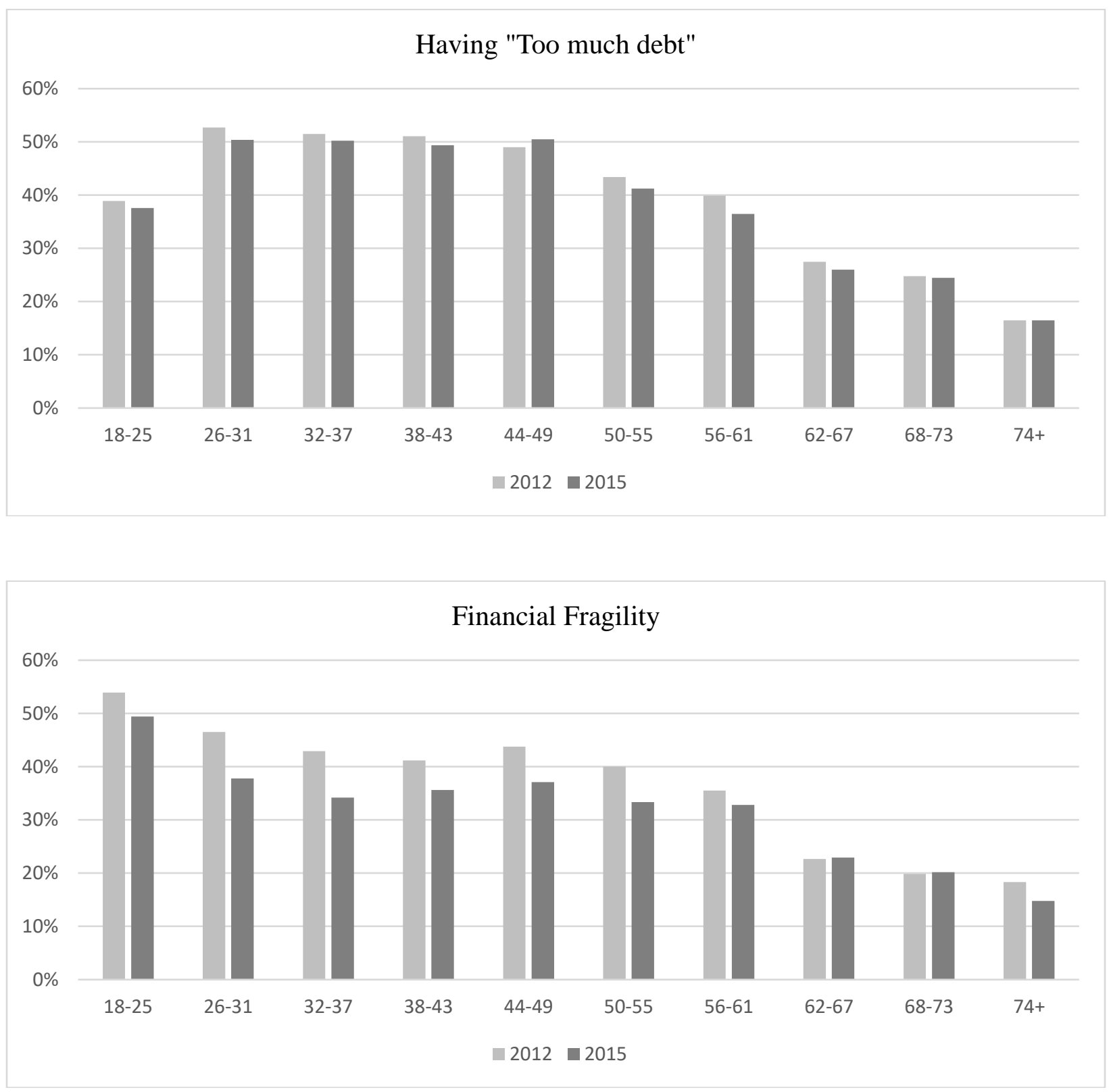

Note: The sample includes all age-eligible individuals 56-61 in the 2012 and 2015 NFCS; statistics weighted using sample weights. People are classified as having "too much debt" if, on a scale from 1 to 7 , they answered 5, 6, or 7 to the question: "How strongly do you agree or disagree with the following statement: "I have too much debt right now," where 1 means "I strongly disagree" and 7 means "I strongly agree." People are classified as financially fragile if they reported that they certainly or probably could not come up with $\$ 2,000$, in response to the following question: "How confident are you that you could come up with $\$ 2,000$ if an unexpected need arose within the next month?" 